\title{
Skeletal Ghanges during Pregnancy and Lactation in the Rat: Effect of Different Levels of Dietary Calcium
}

\author{
By GABRIELLE M. ELLINGER, J. DUCKWOR'TH AND A. C. DALGARNO \\ Rowett Research Institute, Bucksburn, Aberdeenshire \\ AND M. H. QUENOUILLE \\ Statistics Department, University of Aberdeen
}

(Received 3 February 195I)

It is now well known that the skeleton serves as a store of calcium and phosphorus, and that a part of the mineral requirements of lactation is met by bone resorption. In an earlier communication (Warnock \& Duckworth, 1944) the literature was surveyed and the role of the spongiosa as a source of minerals for lactation in the rat was studied under conditions of adequate calcium intake.

Certain interesting questions about the resorption of bone in lactation and its subsequent repair after lactation remain unanswered. In the first place, the extent to which the response of the skeleton to lactational needs is modified by differences in the level of calcium intake is unknown. Secondly, the extent to which cancellous and compact bone are individually resorbed in lactation and the degree to which these changes can be modified by alterations in calcium intake have not been studied. Thirdly, the extent to which calcium intake affects the capacity of cancellous bone and compact bone to recover after depletion does not seem to have been examined. Fourthly, it is not clear whether resorption of bone is the only process by which minerals are released from skeletal stores to meet the needs of lactation in the calciumdeficient animal. The possibility of demineralization of bone, that is of extraction of the mineral component without resorption of the organic matrix, must also be considered. Finally, it seems that no study has been made of changes in physical dimensions of bone in pregnant and lactating animals receiving diets differing in their calcium content.

The present experiment was designed to answer these questions and to afford an opportunity to study the effects of different dietary calcium levels on the reproductive performance of rats and their ability to rear their young. The diets were composed of natural feeding-stuffs, selected for their low calcium content. Most earlier investigators in this field used synthetic diets.

\section{EXPERIMENTAL}

Experimental design. A factorial design experiment was constructed to study the effects of calcium intake upon reproductive performance, skeletal change and organ size and simultaneously the effects associated with the gestation-lactation cycle. One hundred and forty-four female rats were randomized in twenty-four equal groups, of which six were assigned to each of four diets. Thus, in Tables 7-10, 12 and 13 , each 
figure given under the heading 'Reproductive cycle' represents the mean of six individual values. The rats in the first group on each diet (designated I G) were killed at the end of the first gestation, those in the second group ( $\mathrm{I} L$ ) were killed at the end of the first lactation. The animals of the third group $(2 \mathrm{G})$ completed a cycle of one gestation and the ensuing lactation, were mated again and killed at the second parturition. Those of the fourth group completed two reproductive cycles. Similarly, the ${ }_{3} \mathrm{G}$ and ${ }_{3} \mathrm{~L}$ groups represented the third cycle. For present purposes the term 'reproductive cycle' is used to cover both the gestation phase and the ensuing lactation phase.

Diets. The basal diet and the composition of the four experimental diets prepared from it are given in Table $\mathrm{I}$. Blood meal (low-temperature dried) and dehydrated cod meal were used as sources of protein to keep the calcium content of the basal mixture low. The cod meal was prepared from cooked cod fillets carefully examined to ensure freedom from bone. The cod-liver oil contained 800 i.u. vitamin $A$ and I00 i.u. vitamin $\mathrm{D} / \mathrm{g}$. Calcium carbonate was added at three different levels, with compensatory additions of starch to give constant totals of both. The diets were made up weekly.

Table $\mathrm{I}$. Composition of basal diet and construction of diets $A, B, C$ and $D$

\begin{tabular}{lclc} 
Basal diet & Parts & \multicolumn{1}{c}{ Basal diet } & Parts \\
Ground wheat & 23 & Dehydrated cod meal & 4 \\
Ground oats & 20 & Dried brewer's yeast & 3.5 \\
Ground barley & 20 & Salt & 0.5 \\
Ground maize & 20 & Cod-liver oil & I \\
Blood meal* & 6 & Total & 98
\end{tabular}

* W. and J. Dunlop Ltd., Dumfries.

\begin{tabular}{|c|c|c|c|c|}
\hline \multirow[b]{2}{*}{ Designation } & \multicolumn{3}{|c|}{ Experimental diets* } & \\
\hline & $\begin{array}{c}\text { Basal } \\
\text { diet } \\
\text { (g) }\end{array}$ & $\begin{array}{l}\text { Starch } \\
\text { (g) }\end{array}$ & $\begin{array}{c}\mathrm{CaCO}_{3} \\
(\mathrm{~g})\end{array}$ & $\begin{array}{c}\mathrm{Ca} \text { in } \\
\text { diet } \\
(\%)\end{array}$ \\
\hline A & 980 & $I \cdot 25$ & $18 \cdot 75$ & 0.79 \\
\hline B & 980 & $7 \cdot 50$ & $12 \cdot 50$ & 0.54 \\
\hline $\mathbf{C}$ & 980 & 13.75 & 6.25 & 0.29 \\
\hline D & 980 & $20 \cdot 00$ & 0.00 & 0.04 \\
\hline
\end{tabular}

* All diets contained $18.7 \%$ protein and $0.37 \%$ phosphorus.

Animal management. Females were transferred to mating cages at 105 days of age. At the same time they were changed from the standard rearing ration of the colony (Thomson, 1936) to the appropriate experimental diet, which was fed ad lib. until the animals were killed. Young, active males were introduced to the mating cages at the rate of one to every two females. To avoid any effect of calcium deficiency on the fertility of the males they were only left in the mating cages overnight. During daytime they were kept separate and given the standard ration. No male was used in the same cage on two successive nights and all males were frequently given rests from breeding. Females were transferred from mating to individual cages about 5 days from parturi-

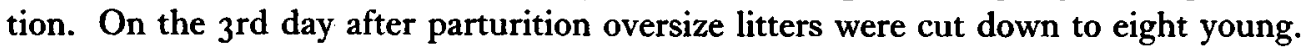


The duration of lactation was 23 days and females not killed at the end of lactation were returned to the mating cages immediately.

Dissection. Animals were killed by coal-gas and dissected rapidly, major blood vessels being severed to aid in draining organs of blood. The surfaces of organs were dried, and weighing was carried out as quickly as possible. The right femur and tibia were freed from most of the adhering flesh, the fibula being discarded. The length of the femur was measured and the bone marked off into thirds. It was cut into three sections using a thin circular saw driven by an electric motor. The cuts were made at right angles to the surface of the bone at the point of section. The distal third of the femur was split into two fractions by separating the condyles from the metaphysis at the epiphyseal line. The four sections of the femur, in order, are referred to below as: the femur head, the femur shaft, the femur metaphysis and the femur condyles.

The tibia was divided into three parts in a similar manner. One cut was made at the point of junction of the tibia and fibula. A second cut was made half-way between the tibia-fibula junction and the proximal end of the tibia. The three sections of the tibia, in order, are referred to below as: the tibia head, the tibia shaft and the tibia distal section.

The different bone sections were freed as completely as possible from marrow by washing with a fine jet of water. Care was taken to avoid breaking off fine spicules of bone from the spongiosa. The portions of bone were then boiled in water and the remaining flesh was dissected off. Uniform cleaning of the medullary cavity close to the spongiosa is impossible unless the contents of the cavity are removed before boiling because of coagulation of the marrow.

Physical measurements. The cross-sectional areas of the proximal and distal surfaces of the femur shaft and tibia shaft of each animal were measured. Camera lucida tracings were made of the four surfaces recording the peripheries of the whole bone and of the medullary cavity. Area measurements of these were made using a planimeter. So that identical magnification would be secured on the various occasions when tracings of bones were taken, an accurately calibrated rectangular brass block, of size similar to the bone cross-sections, was used as a standard. Its image was projected on the tracing paper before each set of tracings, and the magnification adjusted. The term 'total cross-sectional area' is used below to include both the area of cross-section of the bone substance and the area of cross-section of the medullary cavity.

Chemical analysis. The portions of bone were extracted with boiling ethanol and dried to constant weight at $105^{\circ}$. Ashing to constant weight was carried out at $600^{\circ}$.

Presentation of results. Data for the physical measurements and chemical analyses of the various sections of the femur and tibia are tabulated by reproductive cycles and by diets. Organ weights are given in the same style. In each instance the mean values for gestation data and for lactation data are given under each reproductive cycle and for each diet. In addition, the means of all the gestation values and of all the lactation values, together with the mean of all results for each diet, are tabulated in the last three columns of Tables $7^{-10}, 12$ and 13 .

When the animals were randomized among the twenty-four groups there were differences in mean group weight at ros days of age. After the experimental data had 
been collected the effect of differences in initial weight at 105 days was calculated using analyses of covariance. Where the effect of such differences was significant, the regression coefficient indicating the effect and its standard error (s.E.) are given in the table. In these instances the means were adjusted for the differences in initial weight, and such mean group values are referred to as 'adjusted means'.

Below each section of Tables 7-10, 12 and 13 are given the standard errors of differences for the data in the section.

\section{RESULTS}

Reproductive performance. The mean weight increases of pregnant rats during gestation are given in Table 2. No sign ificant difference in weight was found between rats receiving diets $\mathrm{A}, \mathrm{B}$ and $\mathrm{C}$ during any gestation. The mean increase of weight in

Table 2. Mean weight increases of pregnant rats during gestation

\begin{tabular}{|c|c|c|c|}
\hline Diet & $\begin{array}{c}\text { First } \\
\text { gestation } \\
\text { (g) }\end{array}$ & $\begin{array}{c}\text { Second } \\
\text { gestation } \\
\text { (g) }\end{array}$ & $\begin{array}{c}\text { Third } \\
\text { gestation } \\
\text { (g) }\end{array}$ \\
\hline $\begin{array}{l}\text { A } \\
\text { B } \\
\text { C } \\
\text { D }\end{array}$ & 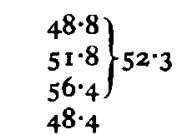 & $\begin{array}{l}\begin{array}{l}41 \cdot 1 \\
36 \cdot 8 \\
38 \cdot 5\end{array} \\
24 \cdot 8\end{array} 3^{8} 8 \cdot 8$ & 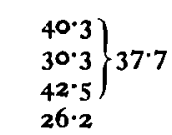 \\
\hline $\begin{array}{l}\text { s.e. of difference } \\
\text { between mean } \\
\text { of } D \text { and mean } \\
\text { of } A-C \text {. }\end{array}$ & \pm 4.40 & \pm 5.53 & $\pm 7 \cdot 08$ \\
\hline
\end{tabular}

Table 3. Mean weight losses of mother rats during lactation

\begin{tabular}{|c|c|c|c|}
\hline Diet & $\begin{array}{l}\text { First } \\
\text { lactation } \\
\text { (g) }\end{array}$ & $\begin{array}{l}\text { Second } \\
\text { lactation } \\
\text { (g) }\end{array}$ & $\begin{array}{l}\text { Third } \\
\text { lactation } \\
\text { (g) }\end{array}$ \\
\hline A & $-18 \cdot 2$ & $-19 \cdot 3^{*}$ & $-28 \cdot 0$ \\
\hline B & -13.0 & -17.8 & $-21 \cdot 5$ \\
\hline C & -10.3 & $-18 \cdot 6^{*}$ & $-20 \cdot 2$ \\
\hline $\mathbf{D}$ & $\rightarrow 18 \cdot 8$ & $-15^{\circ} 4^{*}$ & $-24 \cdot 5$ \\
\hline S.E. of differences & \pm 6.75 & $\pm 5^{\cdot 66}$ & \pm 13.04 \\
\hline
\end{tabular}

diet $\mathrm{D}$ rats was significantly less than the increases in $\operatorname{diet} \mathrm{A}, \mathrm{B}$ and $\mathrm{C}$ rats during the second gestation but not during the first or third. On each diet the mean increases were significantly greater during the first gestation than during the second and third, presumably as a consequence of continued maternal body growth.

Mean decreases in body-weight during lactation are given in Table 3. No significant difference was found between weight losses on the different diets for any lactation period. The weight changes were corrected for the number of survivors per litter. For the second lactation period there was a highly significant negative correlation between the number of survivors and the actual weight changes of the dams (regression coefficient $=3.84 \pm 0.95$ ), but not for the first and third lactations.

The weights of litters at birth and numbers of animals per litter are given in Table 4 . 
The birth weights of first litters were higher than those of subsequent litters, irrespective of diet. The difference arose from the greater number of rats in the first litters. A highly significant negative correlation was found between mean weights of newborn rats and the number of rats in the first litter, but not in the second and third litters. A correction was accordingly made for the first litters but not for the second and third litters.

Table 4. Mean numbers and weights of rats in litters born on different diets

\begin{tabular}{|c|c|c|c|c|}
\hline Litter & Diet & $\begin{array}{l}\text { Mean } \\
\text { weight of } \\
\text { litter } \\
\text { (g) }\end{array}$ & $\begin{array}{c}\text { Mean } \\
\text { number in } \\
\text { litter }\end{array}$ & $\begin{array}{c}\text { Mean } \\
\text { weight per } \\
\text { rat } \\
\text { (g) }\end{array}$ \\
\hline \multirow[t]{2}{*}{ First } & $\begin{array}{l}\text { A } \\
\text { B } \\
\text { C } \\
\text { D }\end{array}$ & $\begin{array}{l}61 \cdot 05 \\
61 \cdot 69 \\
58 \cdot 71 \\
60.69\end{array}$ & $\begin{array}{l}10.89 \\
10.69 \\
10.25 \\
10.86\end{array}$ & $\begin{array}{l}5 \cdot 75 \\
5 \cdot 83 \\
5 \cdot 83 \\
5 \cdot 67\end{array}$ \\
\hline & S.E. of differences & \pm 4.06 & \pm 0.77 & \pm 0.126 \\
\hline \multirow[t]{2}{*}{ Second } & $\begin{array}{l}\mathbf{A} \\
\mathbf{B} \\
\mathbf{C} \\
\mathbf{D}\end{array}$ & $\begin{array}{l}47 \cdot 23 \\
46 \cdot 38 \\
51 \cdot 54 \\
42 \cdot 12\end{array}$ & $\begin{array}{l}7 \cdot 61 \\
7 \cdot 63 \\
8 \cdot 41 \\
7 \cdot 00\end{array}$ & $\begin{array}{l}6 \cdot 25 \\
6 \cdot 17 \\
6 \cdot 20 \\
5 \cdot 93\end{array}$ \\
\hline & S.E. of differences & $\pm 4 \cdot 88$ & \pm 0.81 & \pm 0.178 \\
\hline \multirow[t]{2}{*}{ Third } & $\begin{array}{l}\text { A } \\
\text { B } \\
\text { C } \\
\text { D }\end{array}$ & $\begin{array}{l}49 \cdot 79 \\
43 \cdot 84 \\
44 \cdot 41 \\
34 \cdot 42\end{array}$ & $\begin{array}{l}8 \cdot 27 \\
7 \cdot 33 \\
7 \cdot 00 \\
6 \cdot 00\end{array}$ & $\begin{array}{l}6 \cdot I I \\
6 \cdot 01 \\
6 \cdot 48 \\
5 \cdot 8 I\end{array}$ \\
\hline & S.E. of differences & $\pm 7 \cdot 46$ & $\pm 1 \cdot 23$ & \pm 0.835 \\
\hline
\end{tabular}

The lowest litter birth-weights occurred in litters from animals on diet $\mathrm{D}$ at the second and third parturitions. These lower values arose from a combination of lower individual weights and lower numbers in $\mathrm{D}$ litters. Although the average number of pups born was least in diet $\mathrm{D}$ groups during the second and third cycles, the reduction was not statistically significant.

A further analysis was carried out to test whether the reproductive performances, as indicated by the numbers per litter at birth and the birth weights of litters, were correlated between the three cycles. Animals with poor reproductive performance in the first cycle tended to perform badly in later cycles, but the correlations just failed $(P=0.06)$ to reach the $5 \%$ level of statistical significance. No dietary effect was found in any of these analyses.

The mean weaning weights of rats of different litters from the four dietary groups are given in Table 5. The regression coefficients for the correlation of weight of weanlings and number of animals per litter are also given. At all stages there were highly significant negative correlations between the number of rats in the litter and the average weight of the rats weaned, and the values in the table have been adjusted for these correlations.

There were highly significant reductions in mean weaning weights of diet $D$ rats for all reproductive cycles as compared with corresponding animals from $\mathrm{A}, \mathrm{B}$ and $\mathrm{C}$ dietgroups. The average weaning weights of diet $\mathrm{D}$ rats were about the same for all three 
litters. However, for litters from rats on diets $\mathrm{A}, \mathrm{B}$, and $\mathrm{C}$ the average weight of weanlings was higher in the second and third litters than in the first. These values can be compared with the mean for the stock colony of the Institute during the period of this study, which was $46.09 \mathrm{~g}$.

Table 5. Mean weaning weights of rats from different litters

(All values corrected for the number of rats weaned per litter)

\begin{tabular}{|c|c|c|c|}
\hline Diet & $\begin{array}{l}\text { First } \\
\text { litter } \\
\text { (g) }\end{array}$ & $\begin{array}{l}\text { Second } \\
\text { litter } \\
\text { (g) }\end{array}$ & $\begin{array}{l}\text { Third } \\
\text { litter } \\
\text { (g) }\end{array}$ \\
\hline $\begin{array}{l}\mathbf{A} \\
\mathbf{B} \\
\mathbf{C} \\
\mathbf{D}\end{array}$ & $\begin{array}{l}40 \cdot 7 \\
43 \cdot 1 \\
43 \cdot 9 \\
36.6\end{array}$ & $\begin{array}{l}47^{\circ} \cdot 2 \\
49 \cdot 0 \\
49^{\circ} 1 \\
34^{\circ} \cdot 2\end{array}$ & $\begin{array}{l}45 \cdot 3 \\
44 \cdot 3 \\
55 \cdot 0 \\
36 \cdot 7\end{array}$ \\
\hline S.E. of differences & $\pm 1 \cdot 24$ & \pm 2.09 & \pm 4.02 \\
\hline $\begin{array}{l}\text { Regression } \\
\text { coefficient: } \\
\text { weight/number }\end{array}$ & $-3.61 \pm 0.115$ & $-2 \cdot 88 \pm 0.355$ & $-2.02 \pm 0.612$ \\
\hline
\end{tabular}

In the first reproductive cycle the average weight of diet $\mathrm{A}$ weanlings was less than the values for $\mathrm{B}$ and $\mathrm{C}$ weanlings by an amount that is barely significant. In the third litters the average weight of diet $\mathrm{C}$ weanlings was just significantly more than the values for $A$ and $B$ weanlings.

The data for dams completing three reproductive cycles were analysed separately. There was no evidence of mothers producing consistently heavy or consistently light weanlings.

The number of survivors per litter and numbers of litters successfully reared are given in Table 6.

Table 6. Numbers of rats surviving to weaning together with the number of litters reared in each subgroup

$\begin{array}{cccccc}\text { Diet } & \text { First litter* } & \text { Second litter* } & \text { Third litter* } & \text { Total* } & \begin{array}{c}\text { Percentage } \\ \text { survival }\end{array} \\ \text { A } & 189 / 193(25) \dagger & 99 / 104(15) \dagger & 31 / 38(5) \dagger & 319 / 335(45) \dagger & 95 \cdot 2 \\ \text { B } & 223 / 228(30) & 101 / 108(17) & 23 / 27(4) & 347 / 363(51) & 95 \cdot 6 \\ \text { C } & 193 / 207(27) & 115 / 128(18) & 26 / 31(5) & 334 / 366(50) & 91 \cdot 3 \\ \text { D } & 200 / 206(27) & 92 / 101(16) & 29 / 30(6) & 321 / 337(49) & 95 \cdot 3 \\ \text { Total } & 805 / 834(109) & 407 / 441(66) & 109 / 126(20) & 1321 / 1401(195) & - \\ \text { Percentage } & 96 \cdot 5 & 92 \cdot 3 & 86 \cdot 5 & - & -\end{array}$

- First value gives the total number of survivors at weaning on the $23 \mathrm{rd}$ day; the second value gives the total number of young present on the 3 rd day after oversize litters had been reduced to eight; value in parentheses gives the number of litters reared.

$\uparrow$ Full complement of litters in first-litter subgroups $=30$; in second-litter subgroups $=18$; in thirdlitter subgroups $=6$. Values less than these occur because some litters were born dead, some were killed by their dams and some were neglected.

In twenty-one out of 216 litters the young were either born dead, or the mother failed to rear them. The distribution of failures bore no relation to the diet of the dams.

The percentage of young surviving to the end of lactation fell in successive litters, but there was no significant difference between the dietary groups in the number of young reared. 
Physical measurements of bones. The results from measurements of total crosssectional areas of bones are given in Table 7. Medullary cross-sectional areas, expressed as percentages of the corresponding total cross-sectional areas are tabulated in Table 8. Data for the lengths of the femur and tibia are not given. The average increase in these lengths during the study was about $3 \%$ and no effect due to the level of dietary calcium was found.

Table 7. Influence of level of dietary calcium on dimensions of the total cross-sectional areas of the femur and tibia shafts of rats during gestation and lactation

(All values given in sq.mm. Adjusted means)

\begin{tabular}{|c|c|c|c|c|c|c|c|c|c|}
\hline \multirow{3}{*}{ Diet } & \multicolumn{6}{|c|}{ Reproductive cycle* } & \multirow{2}{*}{\multicolumn{3}{|c|}{ Mean }} \\
\hline & \multicolumn{2}{|c|}{ First } & \multicolumn{2}{|c|}{ Second } & \multicolumn{2}{|c|}{ Third } & & & \\
\hline & $G^{*}$ & $\mathrm{~L}$ & $2 \mathrm{G} *$ & $2 L^{*}$ & $3 G^{*}$ & $3 L *$ & All & $\stackrel{\text { All }}{\text { L's* }}$ & $\begin{array}{c}\text { All } \\
\text { cycles }\end{array}$ \\
\hline \multicolumn{10}{|c|}{ Proximal end of femur shaft } \\
\hline $\begin{array}{l}\text { A } \\
\text { B } \\
\text { C } \\
\text { D }\end{array}$ & $\begin{array}{l}8 \cdot 40 \\
8 \cdot 49 \\
8 \cdot 50 \\
8 \cdot 14\end{array}$ & $\begin{array}{l}8 \cdot 19 \\
8 \cdot 47 \\
8 \cdot 36 \\
7 \cdot 72\end{array}$ & $\begin{array}{l}9 \cdot 03 \\
8 \cdot 53 \\
8 \cdot 75 \\
9 \cdot 10\end{array}$ & $\begin{array}{l}9.01 \\
9.11 \\
9.28 \\
9.09\end{array}$ & $\begin{array}{l}8.95 \\
8.85 \\
9.27 \\
9.98\end{array}$ & $\begin{array}{l}8 \cdot 50 \\
8.87 \\
8 \cdot 99 \\
9 \cdot 29\end{array}$ & $\begin{array}{l}8 \cdot 79 \\
8.62 \\
8.84 \\
9.07\end{array}$ & $\begin{array}{l}8 \cdot 57 \\
8 \cdot 82 \\
8 \cdot 88 \\
8 \cdot 70\end{array}$ & $\begin{array}{l}8.68 \\
8.72 \\
8.86 \\
8.88\end{array}$ \\
\hline \multicolumn{10}{|c|}{$\begin{aligned} \text { Regression coefficient } & =0.013 \pm 0.0020 \\
\text { S.E. } \dagger & =0.305(6) ; 0.176(18) ; 0.124(36)\end{aligned}$} \\
\hline \multicolumn{10}{|c|}{ Distal end of femur shaft } \\
\hline $\begin{array}{l}\text { A } \\
\text { B } \\
\text { C } \\
\text { D }\end{array}$ & $\begin{array}{l}8 \cdot 26 \\
8 \cdot 59 \\
8 \cdot 36 \\
7 \cdot 85\end{array}$ & $\begin{array}{l}8 \cdot 07 \\
8 \cdot 38 \\
8 \cdot 28 \\
7 \cdot 34\end{array}$ & $\begin{array}{l}8 \cdot 24 \\
8 \cdot 09 \\
8 \cdot 45 \\
8 \cdot 39\end{array}$ & $\begin{array}{l}8 \cdot 56 \\
8 \cdot 60 \\
8 \cdot 64 \\
8 \cdot 59\end{array}$ & $\begin{array}{l}8 \cdot 59 \\
7 \cdot 74 \\
8 \cdot 73 \\
9 \cdot 63\end{array}$ & $\begin{array}{l}8 \cdot 06 \\
8 \cdot 27 \\
8 \cdot 47 \\
8 \cdot 80\end{array}$ & $\begin{array}{l}8 \cdot 36 \\
8 \cdot 14 \\
8 \cdot 51 \\
8 \cdot 62\end{array}$ & $\begin{array}{l}8 \cdot 23 \\
8 \cdot 42 \\
8 \cdot 46 \\
8 \cdot 24\end{array}$ & $\begin{array}{l}8 \cdot 30 \\
8 \cdot 28 \\
8 \cdot 48 \\
8 \cdot 43\end{array}$ \\
\hline
\end{tabular}

Regression coefficient $=0.0150 \pm 0.0021$ S.E. $\dagger=0.332$ (6); 0.191 (18); $0.135(36)$

Proximal end of tibia shaft

$\begin{array}{llllllllll}\text { A } & 6.65 & 6.20 & 6.29 & 6.49 & 6.21 & 5.76 & 6.38 & 6.15 & 6.26 \\ \text { B } & 6.55 & 6.27 & 6.16 & 6.43 & 6.07 & 5.95 & 6.26 & 6.22 & \mathbf{6 . 2 4} \\ \text { C } & 6.48 & 6.22 & 6.52 & 6.52 & 6.41 & 6.04 & 6.47 & 6.26 & \mathbf{6 . 3 6} \\ \text { D } & 6.05 & 5.23 & 6.52 & 6.80 & 6.96 & 6.62 & 6.51 & 6.22 & 6.36\end{array}$

Regression coefficient $=0.010 \pm 0.00195$

$$
\text { S.E. } \dagger=0.307 \text { (6); } 0.177 \text { (18); } 0.125(36)
$$

Distal end of tibia shaft

$\begin{array}{llllllllll}\text { A } & 4.06 & 3.92 & 4.24 & 4.75 & 4.39 & 4.15 & 4.23 & 4.27 & 4.25 \\ \text { B } & 4.15 & 4.00 & 4.17 & 4.32 & 4.10 & 4.18 & 4.14 & 4.17 & 4.16 \\ \text { C } & 4.09 & 4.01 & 4.36 & 4.31 & 4.42 & 4.20 & 4.29 & 4.17 & 4.23 \\ \text { D } & 3.93 & 3.93 & 4.23 & 4.41 & 4.86 & 4.43 & 4.34 & 4.26 & 4.30\end{array}$

- See pp. 236, 237.

$$
\begin{aligned}
\text { Regression coefficient } & =0.0078 \pm 0.00034 \\
\text { S.E. } t & =0.171(6) ; 0.099(18) ; 0.070(36)
\end{aligned}
$$

$\dagger$ Figure in parentheses gives the numbers of observations in the means to which the standard error refers.

The total cross-sectional areas of proximal and distal ends of the femur and tibia shafts showed no consistent evidence of continued peripheral growth during the experiment for animals receiving diets $\mathrm{A}, \mathrm{B}$ and $\mathrm{C}$, although there was an indication of an increase in size between the first and second cycles. The trend of diet $D$ rats was significantly different from this. 
During the first reproductive cycle the total cross-sectional areas of the proximal and distal surfaces of the femur and of the proximal surfaces of the tibia of rats on diet $\mathrm{D}$ were significantly less than the corresponding areas for rats on $\operatorname{diet} \mathrm{A}, \mathrm{B}$ or $\mathrm{C}$. For the distal end of the tibia the total cross-sectional area in rats on diet $\mathrm{D}$ was the lowest, but not significantly less than the area for the corresponding diet $\mathrm{A}$ rats. In

Table 8. Influence of level of dietary calcium on the medullary cross-sectional areas, expressed as percentages of the total cross-sectional areas of the femur and tibia shafts, of rats during gestation and lactation

\begin{tabular}{|c|c|c|c|c|c|c|c|c|c|}
\hline & \multicolumn{6}{|c|}{ Reproductive cycle* } & \multirow{2}{*}{\multicolumn{3}{|c|}{ Mean }} \\
\hline & \multirow{2}{*}{\multicolumn{2}{|c|}{ First }} & \multirow{2}{*}{\multicolumn{2}{|c|}{ Second }} & \multirow{2}{*}{\multicolumn{2}{|c|}{ Third }} & & & \\
\hline & & & & & & & All & All & All \\
\hline & I G* & I L* & $2 G^{*}$ & $2 \mathrm{~L} *$ & $3 \mathrm{G}^{*}$ & $3 L^{*}$ & G's* & L's* & cycles* \\
\hline Diet & \multicolumn{9}{|c|}{ Proximal end of femur shaft } \\
\hline $\mathbf{A}$ & $22 \cdot 8$ & $31 \cdot 7$ & $27 \cdot 6$ & $34 \cdot 3$ & $31 \cdot 8$ & $36 \cdot 7$ & 27.4 & $34 \cdot 2$ & $30 \cdot 8$ \\
\hline B & $24 \%$ & $35 \cdot 5$ & $30 \cdot x$ & $38 \cdot 2$ & $29 \cdot 3$ & $36 \cdot 1$ & $27 \cdot 9$ & $36 \cdot 6$ & $32 \cdot 3$ \\
\hline C & $26 \cdot 2$ & 40.9 & $3 I \cdot 6$ & $39^{\cdot 8}$ & $35 \cdot 5$ & $4 I \cdot 6$ & $3 I \cdot I$ & $40 \cdot 8$ & $35 \cdot 9$ \\
\hline D & $26 \cdot 8$ & $51 \cdot 9$ & $39 \cdot 8$ & $57 \cdot 9$ & $46 \cdot 6$ & $52 \cdot 9$ & $37 \cdot 7$ & $54 \cdot 3$ & $46 \cdot 0$ \\
\hline \multicolumn{10}{|c|}{ S.E. of differencest $\pm 2 \cdot 90(6) ; \pm 1.67(18) ; \pm 1 \cdot 18(36)$} \\
\hline \multicolumn{10}{|c|}{ Distal end of femur shaft } \\
\hline A & $32 \cdot 2$ & $37 \cdot 2$ & $35^{\circ} 4$ & $37 \cdot 4$ & $35^{\cdot 6}$ & $40 \cdot 6$ & $34 \cdot 4$ & $38 \cdot 4$ & $36 \cdot 4$ \\
\hline B & $33 \cdot 5$ & 40.1 & $37 \cdot 8$ & $42 \cdot 4$ & $34^{\circ} \circ$ & $40 \cdot 6$ & $35^{\circ} \mathrm{I}$ & $41 \cdot 0$ & $3^{8 \cdot 1}$ \\
\hline C & $33 \cdot 3$ & $46 \cdot 8$ & $37 \cdot 5$ & $43 \cdot 8$ & 39.4 & $45^{\cdot 6}$ & $36 \cdot 7$ & $45 \cdot 4$ & $4 I \cdot I$ \\
\hline D & $33^{\circ} 9$ & $49 \cdot 3$ & $46 \cdot 2$ & $59 \cdot 7$ & $53 \cdot 2$ & $60 \cdot 8$ & $44^{\circ} 4$ & $56 \cdot 6$ & $50 \cdot 5$ \\
\hline \multicolumn{10}{|c|}{ S.E. of differencest $\pm 2 \cdot 38(6) ; \pm I \cdot 38(18) ; \pm 0.97(36)$} \\
\hline
\end{tabular}

\begin{tabular}{|c|c|c|c|c|c|c|c|c|c|}
\hline \multicolumn{10}{|c|}{ Proximal end of tibia shaft } \\
\hline A & 253 & $28 \cdot 4$ & 243 & $27 \cdot 5$ & 24.4 & $27 \cdot 3$ & 247 & $27 \cdot 8$ & $26 \cdot 2$ \\
\hline B & 24.7 & $3 I \cdot 5$ & $24 \cdot 6$ & $30 \cdot I$ & $23 \cdot 2$ & $27 \cdot 5$ & $24 \cdot 2$ & $29 \cdot 7$ & $26 \cdot 9$ \\
\hline C & $26 \cdot 2$ & $34 \%$ & $26 \cdot 9$ & $29 \cdot 0^{\circ}$ & $25 \cdot 8$ & 29.7 & $26 \cdot 3$ & 30.9 & $28 \cdot 6$ \\
\hline $\mathrm{D}$ & $27 \cdot 6$ & $42 \cdot 4$ & $35 \cdot 8$ & $48 \cdot 5$ & $37 \cdot 0$ & $45^{\circ} \cdot 6$ & $33 \cdot 5$ & $45 \cdot 5$ & 39.5 \\
\hline
\end{tabular}

\begin{tabular}{|c|c|c|c|c|c|c|c|c|c|}
\hline \multicolumn{10}{|c|}{ Distal end of tibia shaft } \\
\hline A & $12 \cdot 9$ & $17 \cdot 6$ & 14.7 & 19.8 & 14.3 & 20.9 & 14.0 & 19.4 & $16 \cdot 7$ \\
\hline B & $13 \cdot 6$ & $20 \cdot 3$ & $16 \cdot 0$ & $22 \cdot 7$ & 15.9 & $20 \cdot 9$ & $15 \cdot 2$ & $2 \pi \cdot 3$ & $18 \cdot 2$ \\
\hline C & 13.4 & $28 \cdot 3$ & 15.3 & $23 \cdot 8$ & 19.0 & $25 \cdot 4$ & 15.9 & $25 \cdot 8$ & $20 \cdot 9$ \\
\hline D & $16 \cdot 1$ & $33 \cdot 8$ & $30 \cdot 6$ & $47 \cdot 9$ & $35 \cdot 8$ & $48 \cdot 6$ & $27 \cdot 5$ & 43.4 & $35 \cdot 5$ \\
\hline
\end{tabular}

* See pp. 236, 237.

+ Figure in parentheses gives the number of observations in the means to which the standard error refers.

the third reproductive cycle the situation was reversed at all four surfaces. The mean values for total cross-sectional areas at all four zones during this cycle were significantly greater in rats on diet $D$ than the largest value found in rats receiving $\operatorname{diet} \mathrm{A}, \mathrm{B}$ or $\mathrm{C}$.

The total cross-sectional areas showed no evidence of cyclical changes with gestation and lactation.

When the area of the medullary cavity is expressed as a percentage of the total area of cross-section, increased values represent endosteal erosion. These percentages have 
been used since the total area of cross-section did not vary much in relation to the variation in the medullary cross-sectional area. Further, the use of percentages allowed individual variations in total bone size to be eliminated thus giving slightly more accurate comparisons. (Statistical analyses were in fact also carried out on the area measurements of the medullary cavity, but the results are not included here since they bring out no new feature.) In what follows, reference made to the percentage measurement might equally refer to the area of cross-section of the medullary cavity.

Comparison of the means of all cycles showed that the percentage medullary crosssectional area increased as the level of calcium in the diet was reduced. This was true for all four zones. However, in no instance was the difference between groups receiving diets $\mathrm{A}$ and $\mathrm{B}$ significant. The values for rats on $\operatorname{diet} \mathrm{C}$ were consistently greater than values for rats on either diet $A$ or diet $B$ with one exception-the difference between groups $B$ and $C$ just failed to reach the $5 \%$ level of significance for the proximal end of the tibia shaft. The medullary cross-sectional areas, as a percentage of total areas, of rats fed on diet $D$ were strikingly greater than the values at all four bone surfaces of rats fed on diet $\mathrm{C}$.

The data in Table 8 show the cyclical nature of endosteal erosion during lactation, and repair during the subsequent gestation. These changes occurred with all diets and at all shaft surfaces examined and became progressively greater as the level of calcium intake was reduced. In all instances the cyclical variations of rats on diet D were significantly greater than those of rats receiving other diets, but in no instance could differentiations be made between the variations of groups receiving diets A, B and $C$. Individual comparisons on means of adjacent subgroups sometimes failed to reach the accepted level of statistical significance, probably as a consequence of the relatively small size of the subgroups.

Cycles of erosion during lactation and repair during subsequent gestation occurred with all diets and at all shaft surfaces examined. When rats received $\operatorname{diet} \mathrm{A}, \mathrm{B}$ or $\mathrm{C}$ there was alternating resorption of bone from the surface of the medullary cavity during lactation and new growth of bone at that site during the ensuing gestation. These changes were reflected in the cross-sectional measurements of the medullary cavity. When diet $\mathrm{D}$ was given, an additional factor was involved. Here, because of continued periosteal growth, the recovery phase was characterized by both endosteal and periosteal increases in bone substance. To a minor degree there was some periosteal growth in rats receiving diet A, B or C up to the end of the second lactation, but only in rats on diet $\mathrm{D}$ was there marked periosteal growth at the same time as endosteal growth.

The areas of cross-section of bone substance are not given, but can be calculated from the data in Tables 7 and 8 . The values showed cycles of erosion and repair in most measurements. Bone substance showed reduction in size at the end of lactation for all diets. The mean values for bone substance, when the figures for gestations and lactations were combined, showed progressively smaller cross-sectional areas as the level of calcium in the diet was reduced.

Chemical analyses of bones. Data for ash weight and ash weight expressed as a percentage of dry fat-free bone portions are given in Tables 9 and 12 , respectively. Weights 
Table 9. Influence of level of dietary calcium, pregnancy and lactation on the weight of ash $(\mathrm{mg})$ in sections of the femur and tibia of rats

(Adjusted means)

\begin{tabular}{|c|c|c|c|c|c|c|c|c|c|}
\hline \multirow[b]{3}{*}{ Diet } & \multicolumn{6}{|c|}{ Reproductive cycle* } & \multirow{2}{*}{\multicolumn{3}{|c|}{ Mean }} \\
\hline & \multicolumn{2}{|c|}{ First } & \multicolumn{2}{|c|}{ Second } & \multicolumn{2}{|c|}{ Third } & & & \\
\hline & I G* & I L* & $2 G *$ & $2 L^{*}$ & ${ }_{3} \mathrm{G}^{*}$ & ${ }_{3} L^{*}$ & \multirow{2}{*}{\multicolumn{2}{|c|}{$\overbrace{\text { L's* }}^{\text {All }}$}} & \multirow[t]{2}{*}{$\begin{array}{c}\text { All } \\
\text { cycles }\end{array}$} \\
\hline & \multicolumn{6}{|c|}{ Femur head } & & & \\
\hline A & $121 \cdot 7$ & $90 \cdot 3$ & $124 \cdot 6$ & $107 \cdot 3$ & 130.9 & $94^{\circ} 8$ & 125.7 & 97.5 & III.6 \\
\hline B & 109.9 & 89.0 & $155^{\circ}$ & 107.8 & 122.4 & III.I & 115.8 & 102.6 & $109 \cdot 2$ \\
\hline C & 120.2 & $82 \cdot 0$ & $122 \cdot 6$ & 100.2 & 124.8 & 99.9 & $122 \cdot 5$ & $94 \%$ & $108 \cdot 2$ \\
\hline D & $101 \%$ & 52.9 & 76.8 & $41 \cdot 7$ & $83 \cdot 8$ & $41 \cdot 0$ & $87 \cdot 2$ & $45^{\prime 2}$ & $66 \cdot 2$ \\
\hline \multicolumn{10}{|c|}{$\begin{aligned} \text { Regression coefficient } & =0.232 \pm 0.0462 \\
\text { s.E. } t & =6.3(6) ; 3.63(18) ; 2.57(36)\end{aligned}$} \\
\hline \multicolumn{10}{|c|}{ Femur shaft } \\
\hline & $65 \cdot 4$ & $57 \cdot 8$ & $69 \cdot 3$ & $66 \cdot 7$ & $75 \cdot 8$ & $6 r \cdot 5$ & $70 \cdot 2$ & $62 \cdot 0$ & $66 \cdot 1$ \\
\hline B & 647 & $60 \cdot 6$ & 66.0 & $69 \cdot 0$ & $73^{\circ} \circ$ & $67 \cdot 5$ & $67 \cdot 9$ & $65 \cdot 7$ & $66 \cdot 8$ \\
\hline C & $63 \cdot 0$ & $52 \cdot 6$ & $67 \cdot 7$ & $59 \cdot 8$ & $71 \cdot 2$ & 60.9 & $67 \cdot 3$ & $57 \cdot 8$ & $62 \cdot 6$ \\
\hline D & $6 r \cdot 3$ & $32 \cdot 8$ & $45 \cdot 9$ & $25 \cdot 2$ & $5 \mathrm{r} \cdot 8$ & $27 \cdot 1$ & $53^{\circ} 0$ & $28 \cdot 4$ & 40.7 \\
\hline
\end{tabular}

Regression coefficient $=0 \cdot 135 \pm 0.0291$ S.E. $44 \cdot 67$ (6); $2 \cdot 70(18) ; 1 \cdot 91$ (36)

Femur metaphysis

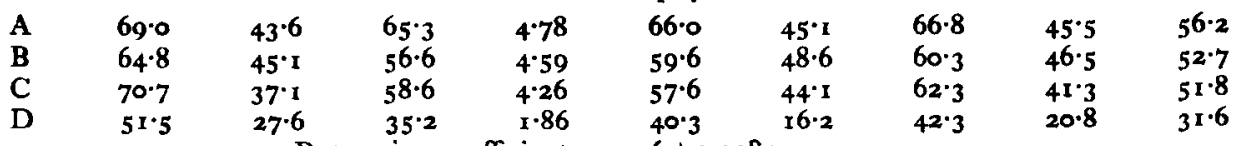

Regression coefficient $=0.116 \pm 0.0284$

S.E. $t=4 \cdot 35(6) ; 2 \cdot 5 x(\mathrm{r} 8) ; x \cdot 78(36)$

Femur condyles

$\begin{array}{llllllllll}\text { A } & 47 \cdot 9 & 35 \cdot 1 & 49 \cdot 9 & 43 \cdot 0 & 54 \cdot 8 & 41 \cdot 8 & 50 \cdot 9 & 40 \cdot 0 & 45 \cdot 4 \\ \text { B } & 45 \cdot 7 & 34 \cdot 9 & 50 \cdot 1 & 45 \cdot 2 & 50 \cdot 6 & 46 \cdot 7 & 48 \cdot 8 & 42 \cdot 3 & 45 \cdot 6 \\ \text { C } & 47 \cdot 5 & 32 \cdot 9 & 50 \cdot 9 & 42 \cdot 2 & 54 \cdot 9 & 40 \cdot 3 & 51 \cdot 1 & 38 \cdot 5 & 44 \cdot 8 \\ \text { D } & 39 \cdot 2 & 22 \cdot 0 & 31 \cdot 9 & 17 \cdot 5 & 37 \cdot 9 & 14 \cdot 6 & 36 \cdot 3 & 18 \cdot 0 & 27 \cdot 2\end{array}$

Regression coefficient $=0.099 \pm 0.0198$ S.E. $t=3.04(6) ; 1.76(18) ; 1.24(36)$

Tibia head

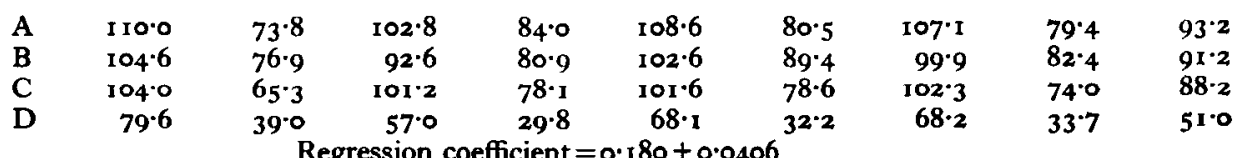

Regression coefficient $=0.180 \pm 0.0406$

S.E. $t=6.45(6) ; 3.72(18) ; 2.63(36)$

Tibia shaft

\begin{tabular}{|c|c|c|c|c|c|c|c|c|c|}
\hline A & $54{ }^{\circ}$ & 49.4 & $58 \cdot 6$ & 60.4 & $62 \cdot 7$ & $53 \cdot 7$ & $58 \cdot 4$ & $54 \cdot 5$ & $56 \cdot 4$ \\
\hline B & 50.1 & $48 \cdot 5$ & $55 \cdot 8$ & 56.0 & $61 \cdot 0$ & $56 \cdot 5$ & 55.6 & 53.7 & 54.6 \\
\hline C & $54^{\circ} 4$ & $44^{\circ} I$ & $57 \cdot 4$ & 52.0 & $6 I \cdot I$ & $52 \cdot 9$ & $57 \cdot 6$ & 49.7 & 53.6 \\
\hline D & $49 \cdot 3$ & 30.7 & 39.9 & 24.8 & $45 \cdot 8$ & $26 \cdot 3$ & $45^{\circ} 0$ & $27 \cdot 3$ & $36 \cdot 2$ \\
\hline
\end{tabular}

Regression coefficient $=0.123 \pm 0.0219$

S.E. $\dagger=3.52(6) ; 2.03(18) ; 1 \cdot 44(36)$

Tibia distal section

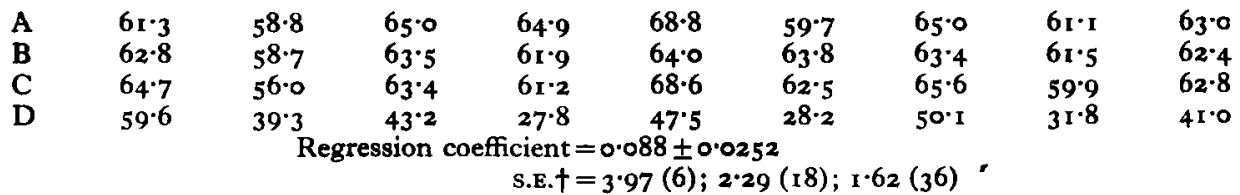

- See pp. 236, 237.

$\uparrow$ Figure in parentheses gives the number of observations in the means to which the standard error refers. 
of dry fat-free bone have been omitted. Their fluctuations did not present any additional feature to warrant special consideration.

Lactation caused a reduction in the quantity of ash (and bone) and was followed by new bone formation during the next pregnancy. In varying degrees, an erosion phase followed by a growth phase was found in every section of the femur and tibia and on all diets. In only three instances was erosion not observed: small increases in ash weight occurred in the tibia-shaft sections of rats on diet $A$ and on $\operatorname{diet} B$ during the second lactation and also in the femur-shaft sections of rats on diet $B$ during the same lactation.

Table 10. Influence of level of dietary calcium, pregnancy and lactation on the ash weight $(\mathrm{mg})$ of the combined femur and tibia of rats

(Adjusted means)

\begin{tabular}{|c|c|c|c|c|c|c|c|c|c|}
\hline \multirow[b]{4}{*}{ Diet } & \multicolumn{6}{|c|}{ Reproductive cycle* } & \multirow{2}{*}{\multicolumn{3}{|c|}{ Mean }} \\
\hline & \multirow{2}{*}{\multicolumn{2}{|c|}{ First }} & \multirow{2}{*}{\multicolumn{2}{|c|}{ Second }} & \multirow{2}{*}{\multicolumn{2}{|c|}{ Third }} & & & \\
\hline & & & & & & & \multirow{2}{*}{$\begin{array}{c}\text { All } \\
\text { G's* }\end{array}$} & \multirow{2}{*}{ All } & \multirow{2}{*}{$\begin{array}{c}\text { All } \\
\text { cycles }\end{array}$} \\
\hline & I $G^{*}$ & I L* & $2 G^{*}$ & $2 \mathrm{~L} *$ & ${ }_{3} G^{*}$ & $3 \mathrm{~L} *$ & & & \\
\hline $\mathbf{A}$ & 528 & 408 & 541 & 473 & 567 & 437 & 545 & 439 & 492 \\
\hline B & 501 & 416 & 495 & 469 & 532 & 485 & 510 & 457 & 483 \\
\hline C & 523 & 369 & 522 & 433 & 541 & $43^{8}$ & 529 & 413 & 471 \\
\hline D & 440 & 264 & 329 & 186 & 374 & 166 & $3^{81}$ & 206 & 293 \\
\hline \multicolumn{9}{|c|}{ Regression coefficient $=1 \cdot 0 \pm 0.21$} & \\
\hline & & & & S.E.t $=$ & $(6) ;$ & 18); & 36) & & \\
\hline
\end{tabular}

- See pp. 236, 237.

+ Figure in parentheses gives the number of observations in the means to which the standard error refers.

The magnitude of the depletion was not the same during all three reproductive cycles. In general, the quantity of ash (and bone) resorbed during the second cycle was less than that during the first and third. This smaller degree of resorption during the second cycle was seen in all sections of the femur and tibia.

Highly significant differences between rats on diet $C$ and diet $D$ were found in the ash weights of all bone sections. In comparisons between rats on diet $B$ and diet $C$ significant differences were found during the lactation phase, but not during the gestation phase. No uniform discrimination was possible between the corresponding means for ash weights from animals on diets $\mathrm{A}$ and $\mathrm{B}$.

The combined ash weights of all sections of the femur and tibia are given in Table ro. Rats fed on diet A, B or C all showed gains in the weight of bone ash during the course of the experiment. The weight of bone ash of rats receiving diet $D$ fell during the same period. A consideration of the summary of all reproductive cycles shows highly significant differentiation between values for ash weight in gestation and lactation. But a comparison between the ash weights of the different dietary groups allows for discrimination only between diets $\mathrm{A}, \mathrm{B}$ and $\mathrm{C}$ combined and $\operatorname{diet} \mathrm{D}$. The one exception is a significant difference amongst the 'all lactation' values-the mean ash weight of bones from diet $B$ rats was significantly greater than that of the bones from diet $\mathrm{C}$ rats. 
The slight increase in bone length, referred to above, was reflected in the general increase in ash weights (and bone substance) of all portions except the distal portion of the tibia. In place of the overall increase in bone size of rats receiving $\operatorname{diet} \mathrm{A}, \mathrm{B}$ or $\mathrm{C}$ a decrease occurred in the quantity of bone in animals on diet $D$. This decrease appeared to be complete by the end of the second lactation, and the values obtained for ash (and bone) in the different portions at the end of the third lactation were not markedly different from those previously found.

Table I I. Absolute and relative losses of ash during lactation from different parts of the femur and tibia of rats; mean values for three lactations

\begin{tabular}{|c|c|c|c|c|c|}
\hline \multirow[b]{2}{*}{ Bone } & \multirow[b]{2}{*}{$\begin{array}{l}\text { Bone } \\
\text { section }\end{array}$} & \multicolumn{2}{|c|}{$\begin{array}{c}\text { Diets A, B and C } \\
\text { Ash lost }\end{array}$} & \multicolumn{2}{|c|}{$\begin{array}{c}\text { Diet D } \\
\text { Ash lost }\end{array}$} \\
\hline & & $\begin{array}{l}\text { Weight } \\
\text { (mg) }\end{array}$ & (\%) & $\begin{array}{l}\text { Weight } \\
\text { (mg) }\end{array}$ & $(\%)$ \\
\hline Femur & $\begin{array}{l}\text { Head } \\
\text { Shaft } \\
\text { Metaphysis } \\
\text { Condyles }\end{array}$ & $\begin{array}{r}23 \cdot 3 \\
6 \cdot 6 \\
18 \cdot 7 \\
10 \cdot 0\end{array}$ & $\begin{array}{r}19 \cdot 2 \\
9 \cdot 7 \\
29 \cdot 6 \\
19 \cdot 9\end{array}$ & $\begin{array}{l}42 \cdot 0 \\
24 \cdot 6 \\
21 \cdot 5 \\
18 \cdot 3\end{array}$ & $\begin{array}{l}48 \cdot 2 \\
46 \cdot 4 \\
50 \cdot 8 \\
50 \cdot 4\end{array}$ \\
\hline Tibia & $\begin{array}{l}\text { Head } \\
\text { Shaft } \\
\text { Distal section }\end{array}$ & $\begin{array}{r}24.5 \\
4.6 \\
3.8\end{array}$ & $\begin{array}{r}23 \cdot 8 \\
8 \cdot 0 \\
5 \cdot 9\end{array}$ & $\begin{array}{l}34 \cdot 5 \\
17 \cdot 7 \\
18 \cdot 3\end{array}$ & $\begin{array}{l}50 \cdot 6 \\
39 \cdot 3 \\
36 \cdot 5\end{array}$ \\
\hline
\end{tabular}

The combined femur and tibia ash showed the following losses in $\mathrm{mg}$ during the first, second and third lactation, respectively: $\operatorname{diet} \mathrm{A}_{120}, 68$, I30$^{\circ}$; diet $\mathrm{B} 85,26,47$; diet $\mathrm{C}_{154}, 89$, 103; diet $\mathrm{D}_{17} 76,143,208$. In all three reproductive cycles, drafts from rats receiving diets $\mathrm{A}$ and $\mathrm{C}$ were similar, but losses from both these groups were greater than from rats receiving diet B. However, this difference failed to reach statistical significance.

The absolute and relative losses of ash from the various bone portions during lactation are given in Table Ir. Combined average values for diets $\mathrm{A}, \mathrm{B}$ and $\mathrm{C}$ are compared with values for diet $\mathrm{D}$. Under all dietary conditions the distal portion of the tibia showed the least evidence of resorption during lactation. The shaft portions also showed only slight resorption, except when the level of dietary calcium was very low. Then the femur shaft in particular showed a loss of ash approaching that of the femur head and metaphysis-portions that consistently lost the greatest proportion of ash during lactation.

A distinct cycle was observed in the percentage of ash in all portions of bone from animals receiving diet $\mathrm{D}$. Lactation was always accompanied by a decrease in the percentage of ash, and pregnancy by an increase. Bone sections from animals fed $\operatorname{diet} \mathrm{A}, \mathrm{B}$ or $\mathrm{C}$ did not juniformly exhibit ithe same cyclical changes, although the indication of a cycle could be discerned in most cases.

Means of all gestation and lactation values for the percentage of ash differed significantly in all portions of bone from rats receiving diet $D$. Significant differences were not uniformly observed in animals receiving other diets. When the corresponding values for animals receiving diet $A, B$ or $C$ are combined, significant depressions of 
Table 12. Influence of level of dietary calcium, pregnancy and lactation on the percentage of ash in sections of the femur and tibia of rats

(Regression coefficients not significant)

Reproductive cycle*

\begin{tabular}{|c|c|c|c|c|c|c|c|c|}
\hline \multirow[b]{2}{*}{ Diet } & First & \multicolumn{2}{|c|}{ Second } & \multicolumn{2}{|c|}{ Third } & \multicolumn{3}{|c|}{ Mean } \\
\hline & $x \mathrm{G}^{*}$ & $2 G^{*}$ & $2 \mathrm{~L}^{*}$ & ${ }_{3} G^{*}$ & $3 \mathrm{~L}^{*}$ & $\begin{array}{c}\text { All } \\
\text { G's }\end{array}$ & $\begin{array}{c}\text { All } \\
\text { L's* }\end{array}$ & $\begin{array}{c}\text { All } \\
\text { cycles* }\end{array}$ \\
\hline
\end{tabular}

Femur head

$\begin{array}{llllllllll}\text { A } & 71 \cdot 3 & 68 \cdot 3 & 70 \cdot 5 & 71 \cdot 5 & 71 \cdot 2 & 68 \cdot 3 & 71 \cdot 0 & 69 \cdot 4 & 70 \cdot 2 \\ \text { B } & 70 \cdot 8 & 67 \cdot 4 & 70 \cdot 4 & 69 \cdot 2 & 71 \cdot 1 & 69 \cdot 1 & 70 \cdot 8 & 68 \cdot 6 & 69 \cdot 7 \\ \text { C } & 70 \cdot 7 & 67 \cdot 2 & 70 \cdot 2 & 68 \cdot 6 & 70 \cdot 4 & 70 \cdot 1 & 70 \cdot 4 & 68 \cdot 6 & 69 \cdot 5 \\ \text { D } & 69 \cdot 8 & 62 \cdot 3 & 65 \cdot 0 & 54 \cdot 7 & 64 \cdot 6 & 50 \cdot 0 & 66 \cdot 5 & 55 \cdot 7 & 61 \cdot 1\end{array}$

Femur shaft

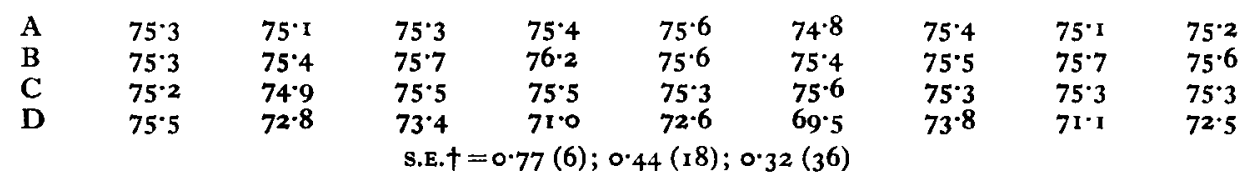

$\begin{array}{cccccccccc}\text { A } & 70 \cdot 0 & 68 \cdot 5 & 70 \cdot 5 & 65 \cdot 8 & 69 \cdot 6 & 67 \cdot 8 & 70 \cdot 0 & 67 \cdot 4 & 68 \cdot 7 \\ \text { B } & 70 \cdot 2 & 68 \cdot 1 & 69 \cdot 8 & 68 \cdot 7 & 69 \cdot 7 & 68 \cdot 2 & 69 \cdot 9 & 68 \cdot 3 & 69 \cdot 1 \\ \text { C } & 70 \cdot 0 & 67 \cdot 0 & 68 \cdot 8 & 67 \cdot 6 & 68 \cdot 3 & 67 \cdot 0 & 69 \cdot 0 & 67 \cdot 2 & 68 \cdot 1 \\ \text { D } & 68 \cdot 4 & 61 \cdot 6 & 64 \cdot 9 & 56 \cdot 0 & 64 \cdot 3 & 50 \cdot 5 & 65 \cdot 8 & 56 \cdot 1 & 61 \cdot 0\end{array}$

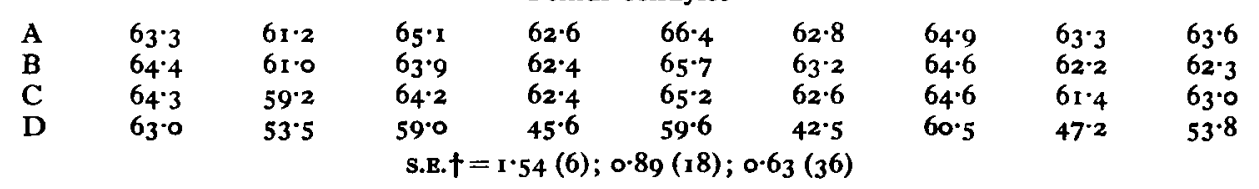

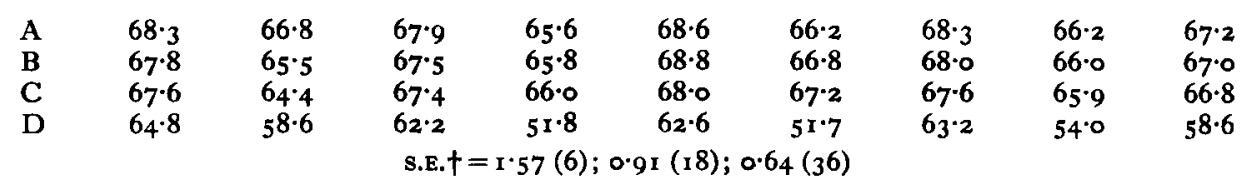

\begin{tabular}{|c|c|c|c|c|c|c|c|c|c|}
\hline \multicolumn{10}{|c|}{ - } \\
\hline A & $74^{\circ} \mathrm{I}$ & $74^{\circ} 5$ & 74.5 & $74 \cdot 8$ & 73.9 & $73 \cdot 5$ & $74 \cdot 2$ & $74 \cdot 3$ & $74 \cdot 2$ \\
\hline B & 73.0 & $74^{\circ} 9$ & $74^{\prime 2}$ & 74.7 & 74.4 & $73 \cdot 9$ & 73.9 & $74 \cdot 5$ & $74 \cdot 2$ \\
\hline C & 74.0 & 74.3 & $74^{\circ} \circ$ & $74 \cdot 3$ & $74^{\prime} 2$ & $74^{\circ} 9$ & $74^{-1}$ & 745 & $74 \cdot 3$ \\
\hline D & $74 \cdot 5$ & $73 \cdot 1$ & $72 \cdot 6$ & 70.5 & $71 \cdot 6$ & $69 \cdot 2$ & $72 \cdot 9$ & 70.9 & 7199 \\
\hline
\end{tabular}

S.E. $\mathrm{t}=0.59(6) ; 0.34(18) ; 0.24(36)$

\begin{tabular}{|c|c|c|c|c|c|c|c|c|}
\hline A & $70 \cdot 7$ & 70.2 & 70.8 & $68 \cdot 7$ & $7 r \cdot 1$ & $70 \cdot 4$ & $70 \cdot 9$ & 69.8 \\
\hline B & 70.7 & $69 \cdot 6$ & 70.7 & $70 \cdot 6$ & $7 \mathrm{I} \cdot \mathrm{I}$ & 70.5 & 70.8 & $70 \cdot 2$ \\
\hline $\begin{array}{l}\text { C } \\
\text { D }\end{array}$ & $\begin{array}{l}70 \cdot 1 \\
69 \cdot 7\end{array}$ & $\begin{array}{l}67.8 \\
68.6\end{array}$ & $\begin{array}{l}70 \cdot 1 \\
69.6\end{array}$ & $\begin{array}{l}68 \cdot 7 \\
65 \cdot 0\end{array}$ & $\begin{array}{l}70 \cdot 7 \\
68 \cdot 4\end{array}$ & $\begin{array}{l}7 r \cdot 3 \\
65 \cdot 4\end{array}$ & $\begin{array}{l}70 \cdot 3 \\
69 \cdot 2\end{array}$ & $\begin{array}{l}69 \cdot 3 \\
66 \cdot 3\end{array}$ \\
\hline
\end{tabular}

- See pp. 236,237 .

S.E. $f=0.96(6) ; 0.55(18) ; 0.39(36)$

+ Figure in parentheses gives the number of observations in the means to which the standard error refers. 
percentage ash in lactation are found for the femur head, metaphysis and condyles and for the tibia head and distal section.

In rats on diet $\mathrm{D}$, percentage-ash values tended to decrease progressively. This tendency was most marked in those portions of bone that exhibited the greatest degree of depletion-head, metaphysis and condyles of the femur and the head of the tibia.

Organ weights. Adjusted mean values for weight of spleens and ovaries and unadjusted mean values for weight of thyroids are given in Table 13. There was no evidence of continued growth of liver during the experiment and no cycle during

Table 13. Influence of level of dietary calcium, pregnancy and lactation on the mean weights of spleens, ovaries and thyroids of rats

\begin{tabular}{|c|c|c|c|c|c|c|c|c|c|}
\hline \multirow{4}{*}{ Diet } & \multicolumn{6}{|c|}{ Reproductive cycle* } & \multirow{2}{*}{\multicolumn{3}{|c|}{ Mean }} \\
\hline & \multicolumn{2}{|c|}{ First } & \multicolumn{2}{|c|}{ Second } & \multicolumn{2}{|c|}{ Third } & & & \\
\hline & & & & & & & \multirow{2}{*}{$\begin{array}{l}\text { All } \\
\text { G's" }\end{array}$} & \multirow{2}{*}{$\begin{array}{c}\text { All } \\
\text { L's* }\end{array}$} & \multirow{2}{*}{$\begin{array}{c}\text { All } \\
\text { cycles }\end{array}$} \\
\hline & I $G^{*}$ & $1 \mathrm{~L}^{*}$ & $\mathbf{2} \mathrm{G}^{\mathbf{*}}$ & $2 \mathrm{L*}$ & $3 G^{*}$ & $3^{L *}$ & & & \\
\hline & \multicolumn{9}{|c|}{ Spleen (adjusted weight in g). Adjusted means } \\
\hline A & 1.05 & 0.88 & 1.08 & 0.89 & 0.99 & I.0I & $\mathrm{I} \cdot 04$ & 0.93 & 0.98 \\
\hline B & 1.00 & 0.94 & 0.99 & 1.06 & $x \cdot 09$ & 0.96 & $1 \cdot 03$ & 0.99 & r.or \\
\hline C & 1.36 & 0.90 & $1 \cdot 20$ & 0.92 & $1 \cdot 11$ & $1 . \infty$ & $1 \cdot 22$ & 0.94 & $1 \cdot 08$ \\
\hline D & $1 \cdot 23$ & $\mathbf{0 . 9 1}$ & $1 \cdot 17$ & 0.86 & $\mathbf{1} \cdot \mathbf{3} \mathbf{x}$ & 0.93 & $1 \cdot 24$ & 0.90 & $1 \cdot 07$ \\
\hline \multicolumn{10}{|c|}{$\begin{aligned} \text { Regression coefficient } & =0.002 \times 8 \pm 0.00071 \\
\text { S.E. } \dagger & =0.114(6) ; 0.066(18) ; 0.046(36)\end{aligned}$} \\
\hline
\end{tabular}

Ovaries (adjusted weight in $\mathrm{mg}$ ). Adjusted means

\begin{tabular}{|c|c|c|c|c|c|c|c|c|}
\hline $\begin{array}{l}\text { A } \\
\text { B }\end{array}$ & $\begin{array}{l}93.3 \\
85.0\end{array}$ & $\begin{array}{l}50.3 \\
56 \cdot 6\end{array}$ & $\begin{array}{l}96 \cdot 1 \\
99 \cdot 4\end{array}$ & $\begin{array}{l}6 \cdot \cdot 1 \\
64 \cdot 3\end{array}$ & $\begin{array}{l}100.4 \\
100.0\end{array}$ & $\begin{array}{l}68 \cdot 6 \\
78 \cdot 5\end{array}$ & $\begin{array}{l}96.7 \\
94.8\end{array}$ & $\begin{array}{l}60.0 \\
66.5\end{array}$ \\
\hline 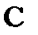 & $83 \cdot 2$ & $55^{\cdot 2}$ & 95.5 & $58 \cdot 4$ & 107.2 & $76 \cdot I$ & 95.4 & $63 \cdot 2$ \\
\hline & 103.9 & $57 \cdot 3$ & 100.0 & 59.1 & 97.8 & $65 \cdot 6$ & $100 \cdot 5$ & $60 \cdot 6$ \\
\hline
\end{tabular}

Regression coefficient $=0.154 \pm 0.053$ S.E. $\dagger=8.56(6) ; 4.94(18) ; 3.49(36)$

Thyroid (weight in $\mathrm{mg}$ )

$\begin{array}{llllllllll}\text { A } & 24 \cdot 1 & 26 \cdot 0 & 41 \cdot 2 & 36 \cdot 5 & 43 \cdot 1 & 39 \cdot 9 & 36 \cdot 1 & 34 \cdot 1 & 35 \cdot 1 \\ \text { B } & 21 \cdot 5 & 32 \cdot 3 & 38 \cdot 7 & 41 \cdot 7 & 41 \cdot 0 & 45 \cdot 8 & 33 \cdot 8 & 39 \cdot 9 & 36 \cdot 8 \\ \text { C } & 23 \cdot 4 & 25 \cdot 1 & 35 \cdot 7 & 38 \cdot 8 & 39 \cdot 0 & 42 \cdot 2 & 32 \cdot 7 & 35 \cdot 4 & 34 \cdot 0 \\ \text { D } & 25 \cdot 3 & 32 \cdot 3 & 30 \cdot 3 & 32 \cdot 1 & 32 \cdot 7 & 31 \cdot 5 & 29 \cdot 4 & 32 \cdot 0 & 30 \cdot 7\end{array}$

- See pp. 236, 237.

Regression coefficient not significant

+ Figure in parentheses gives the number of observations in the means to which the standard error refers.

pregnancy and lactation. Kidneys continued to grow throughout the experiment from a mean value of $2.07 \mathrm{~g}$ during the first reproductive cycle to $2.32 \mathrm{~g}$ during the third. The increase was accounted for by continued growth of the body. There was no cycle in kidney size during pregnancy and lactation. The adrenals showed a significant decrease of about $7 \%$ during the experiment, but pregnancy and lactation had no specific effect on size.

For the spleen there was a highly significant difference between the mean values for all gestations and all lactations. The gestation values of animals receiving diets $\mathrm{C}$ and $\mathrm{D}$ were about $20 \%$ higher than those of animals receiving diets A and B. At the end of lactation the effect of diet on spleen weight had disappeared. 
All groups showed a cycle in ovary weight during each reproductive cycle. There was a steady increase in the mean weights of ovaries throughout the experiment in animals receiving diet $\mathrm{A}, \mathrm{B}$ or $\mathrm{C}$. In the rats on diet $\mathrm{D}$ there was a larger increase during the first pregnancy and thereafter the mean size was maintained, though the difference between $\mathrm{D}$ and the other diets is not fully significant.

There was continued growth of the thyroid gland throughout the experiment on all diets. The increases were greater than could be accounted for by increases in bodyweight in rats receiving diets $\mathrm{A}, \mathrm{B}$ and $\mathrm{C}$. In rats on diet $\mathrm{D}$ the growth was less than that on the other diets.

\section{DISCUSSION}

The above results show that bone resorption during lactation and bone replacement during the next gestation were found in all regions of the femur and tibia irrespective of the level of dietary calcium. Different parts of these bones contributed widely different quantities of mineral during the resorption phase. The zones rich in cancellous bone-the head and metaphysis section of the femur and the head of the tibia-were the prime sources of mineral when the dietary provision of calcium was near to adequacy. The quantity of mineral contributed by the condyles of the femur was less, although the proportion eroded was similar.

The portions mainly composed of compact bone-the shaft of the femur and the shaft and distal portion of the tibia-were less subject to resorption. They contributed but little mineral, either absolutely or relatively, unless the diet was very inadequate in calcium. When this happened, the compact bone was attacked and the proportion resorbed was almost as great as in the more labile cancellous zones. The distal portion of the tibia remained at all times less subject to resorption than other regions of compact bone.

If the shaft portions are taken to represent true bone, contaminated with but minimal amounts of marrow and with relatively few vascular channels to retain nonosseous material, there was no evidence of selective solution of mineral from the organic matrix of bone in this experiment. Should a partial demineralization of the organic matrix take place during the resorptive changes of lactation, cycles would be seen in the percentages of ash in the shaft sections. This was not found. No cyclical variation in the percentage of ash in shafts occurred in rats eating $\operatorname{diet} \mathrm{A}, \mathrm{B}$ or $\mathrm{C}$, though in diet $\mathrm{D}$ rats there were slight but significant cyclical changes. Even though the leg bones of the diet $\mathrm{D}$ animals were eroded to the extent of losing almost half their mineral content, the percentage of ash in the shaft portions fell only by $3-5 \%$. It is even doubtful whether this small reduction in the percentage of ash was real; microscopic examination of the bones of rats on diet D showed the small cavities, which characterize porotic bone, filled with organic debris.

In the zones that are rich in cancellous bone the cycles in the percentage of ash are probably spurious. It is not likely that demineralization occurred in that portion of bone constituting the spongiosa yet failed to occur in compact bone. Those bone portions containing large amounts of spongiosa had only a small proportion of the non-osseous organic matter in the interstices removed by our cleaning method. In 
resorption of spongiosa the weight of true bone decreases but the amount of nonosseous organic material remains unaltered, or may even increase as this material takes the place of resorbed bone spicules. Only a portion of this non-osseous organic material is removed during ethanol extraction, the remainder appearing in analysis indistinguishable from bone organic matrix.

This view on bone resorption in lactation agrees with the histological observations that when bone resorption is provoked by dosing with parathyroid hormone the organic matrix and bone salt disappear simultaneously without preliminary demineralization or even the formation of osteoid borders (McLean \& Bloom, 194I). Further evidence supporting a view of general uniformity of composition of uncontaminated bone was given by Baker, Butterworth \& Langley (1946) who studied the composition of true bone cleaned by microdissection. They found no difference in calcium and nitrogen content of femur cortex and femur cancellous bone, or between dead (sequestra) and living bone. Only between the cancellous bone of infant ribs and the cancellous bone of adult ribs did they find a slight but significant difference in ash content: $62.7 \%$ for the infant and $65.8 \%$ for the adult.

The level of calcium in the diet was without effect on the total cross-sectional areas of the femur and tibia, except with the diet of lowest calcium content. When the diet contained only $0.04 \%$ calcium, these external dimensions of the bones were smaller than those of rats fed on the other diets in the first reproductive cycle. During the course of the experiment the bones of rats fed on diet D gradually increased in size until, by the end of the third lactation, they were equal to, or larger than, the bones of the rats fed on the higher calcium diets. It appears that the capacity for external, or periosteal, bone growth is not impaired by calcium deficiency, even when this dietary deficiency is intensified by periods of calcium loss in lactation.

Selection of the points at which to cut the leg bones to expose surfaces for measurement was made so that these surfaces differed in their proximity to cancellous bone. It was originally thought that there might be a greater degree of erosion of compact bone in regions close to actively resorbing masses of spongiosa. This was not so as far as the surfaces we selected to expose were concerned. Erosion took place during lactation at all medullary surfaces, and no particular zone gave a better indication of the effect of the different diets.

An opportunity is presented by these results to compare physical methods of bone examination with chemical methods for the purpose of discriminating between diets in their capacity to minimize drafts on the skeleton. Both methods of measurement allow discrimination between the effects of diet $\mathrm{D}$ and all other diets. However, such discrimination is of little value since diet $\mathrm{D}$ is patently inadequate in calcium. In the comparison of diets $\mathrm{B}$ and $\mathrm{C}$ both the chemical method and the physical method, when the area of cross-section of the medullary cavity is expressed as a percentage of the total area of cross-section of the bone, are equally satisfactory. On the other hand, neither method discriminates consistently between the effects of diets A and B.

Cox \& Imboden (1936) concluded that $0.49 \%$ calcium in the diet of rats was the most suitable level for sustaining repeated pregnancies and lactations in the mother and normal weaning weight and ash content in the young. Diet $B$ of the present 
experiment had a similar calcium content $(0.54 \%)$, and the lactation drafts on the skeleton were significantly less when this diet was given than when diet $\mathrm{C}$ was fed. However, the combined femur- and tibia-ash weights were not significantly lower for $\operatorname{diet} \mathrm{C}$ rats than for diet $\mathrm{B}$ rats. The effect of the lower calcium intake on bone is thus restricted to greater losses in lactation with correspondingly greater new bone growth after lactation. It is interesting to note that increasing the calcium content of the diet by $50 \%$, as in diet $\mathrm{A}$, or decreasing it by $50 \%$, as in $\operatorname{diet} \mathrm{C}$, was without an effect beyond this slight increase in resorption and repair in diet $\mathrm{C}$ rats.

These changes found for leg bones probably reflect the changes in the skeleton as a whole. In the present study the diet $D$ rats lost $40 \%$ of the combined femur and tibia ash during the first lactation. During the subsequent gestation $37 \%$ of the loss was made good by new leg-bone growth. Comparable data for the whole skeleton of rats given diet $\mathrm{D}$ show that $32 \%$ of the total skeletal ash was lost during the first lactation and that $40 \%$ of the loss was regained during a subsequent period of 3 weeks (unpublished data).

Although diet $\mathrm{D}$ was markedly deficient in calcium, as shown by the state of the bones, the shortage had little effect on reproduction and mothering instinct. The fertility of the dams was unaltered and the survival of their young was unaffected. Their capacity to produce litters of normal size was but slightly impaired and their tendency to gain less in weight during pregnancy was, perhaps, a reflexion of this. The smaller weaning weights of litters from females eating diet $D$ were probably the outcome of calcium deficiency reducing milk production. Nevertheless, complete failure of lactation was no more common in these females than in others with more plentiful supplies of calcium, even under the severe strain of repeated pregnancies and lactations.

In the experience of some other groups of workers, breeding and nursing performance is impaired by calcium deficiency. Boelter \& Greenberg (1943) found that, when adult female rats were transferred to a diet severely deficient in calcium ( $(0.01 \%)$, only half of them produced litters, in spite of repeated matings, and that the majority of the litters was either still-born or the young died shortly after birth. To secure a repetition of pregnancy to the stage of producing two litters was almost impossible. However, they found that females transferred to their deficient diet when adult, but not earlier, had normal oestrous cycles, that six to eight pups were usually born in each litter and that the average weight of the pups was normal.

Bodansky \& Duff (1941 $a, b$ ), using the diets of Cox \& Imboden (1936), reported that, even when the calcium content of the diet was as low as $0.017 \%$ (phosphorus content $0.245 \%$ ), there was little effect on the size or weight of litters. But they found, as did Cox \& Imboden, that the fertility of the females fell to about $50 \%$.

The divergence of our results from those of other workers is mainly in connexion with the fertility of the dams and the viability of the newborn. The principal difference between our experiments and those mentioned above is that our diet was composed of natural feeding-stuffs whereas theirs were' synthetic. In addition, our male rats received a diet adequate in calcium. This raises the question of whether other inadequacies may have characterized the synthetic diets. In fact, Boelter \& Greenberg 
(1943) emphasize that their deficient diet, when supplemented with calcium, yielded inferior results to that of their normal stock diet. Simmonds (1924), using a natural diet, although with casein as the main source of protein and containing more calcium ( $0.103 \%$ ), secured good reproduction but some interference with lactation, as judged by the growth of litters and the general weakening of the dams.

It seems probable that an uncomplicated deficiency of calcium in the diet of the rat has only a small effect on reproductive processes and a moderate effect on lactation. In other words, the avidity of the depleted maternal skeleton for calcium, in the face of an inadequate dietary supply, does not impair reproduction, but the rate at which the maternal skeleton can yield calcium to remedy a severe shortage in lactation is below that necessary to sustain a full flow of milk. It is to be emphasized that these results were obtained with fernales reared on an adequate diet from birth to the beginning of their first pregnancy. Also it is doubtful whether comparable results would be obtained in species where the young are more mature at birth than rat pups. The calcium content of the rat litter is low, the foetal skeletons not competing seriously with the maternal skeleton for calcium. In other species-for example sheep-the reverse is true: the ewe can lose bone substance during gestation on a low-calcium diet while the foetus develops an almost normal skeleton. Where the foetus is a serious competitor for meagre calcium supplies a detrimental effect on the reproductive performance of the dam might be expected.

The reason for enlargement of the spleen during gestation in rats receiving diets $\mathrm{C}$ and $D$ is not clear. It was the only change in an organ that allowed discrimination between the effects of diets $B$ and $C$. 'The condition was not a reflexion of the degree of calcium deficiency, for the enlargement was of the same order in both $\operatorname{diet} C$ and $D$ rats.

Neither the stage of the reproductive cycle nor the level of dietary calcium affected other organ weights, except those of the ovaries. Here cyclical changes of the same order as those reported by Perlman \& Leonard (1947) were found. The greater increase in ovary weight during the first reproductive cycle in calcium-deficient rats is of obscure significance.

\section{SUMMARY}

I. Bone growth and bone erosion in rats fed on diets of different calcium content during gestation and lactation have been studied.

2. During lactation erosion occurred irrespective of the level of calcium intake.

3. Erosion was confined principally to regions rich in cancellous bone, but resorption of the shaft bone at the surface of the medullary cavity was found in all regions.

4. There was no evidence of selective solution of bone mineral independent of erosion.

5. In a comparison between chemical and physical methods of bone examination, certain physical measurements provided as accurate a means for discriminating between the effect of diets of different calcium content as chemical methods.

6. The weights of liver, kidneys, adrenals and thyroid were not affected by differences in the calcium content of diets. At the end of the first gestation ovaries from severely calcium-deficient rats were considerably heavier than ovaries from adequately 
fed rats. The spleens of rats with lower calcium intakes showed a weight gain during gestation which disappeared during the subsequent lactation.

7. Fertility of the dam and mothering instinct were not impaired, even in severe calcium deficiency. The weight of the young at birth and the number of young in a litter were not affected by the level of calcium intake by the dam. Weaning weights of young from severely deficient dams were lower.

\title{
REFERENCES
}

Bakex, S. L., Butterworth, E. C. \& Langley, F. A. (1946). Biochem. J. 40, 391.

Bodansky, M. \& Duff, V. B. (1941 a). $\mathscr{F}$. Nutrit. 21, 179 .

Bodansky, M. \& Duff, V. B. (1941 b). F. Nutrit. 22, 25.

Boelter, M. D. D. \& Greenberg, D. M. (1943). F. Nutrit. 26, 105.

Cox, W. M. \& Imboden, M. (1936). f. Nutrit. I1, I47.

McLean, F. C. \& Bloom, W. (1941). Arch. Path. 32, 315.

Perlman, P. L. \& Leonard, S. L. (1947). Proc. Soc. exp. Biol., N.Y., 66, 24.

Simmonds, N. (1924). Amer. Y. Hyg. 4, I.

Thomson, W. (1936). F. Hyg., Camb., 36, 24.

Warnock, G. M. \& Duckworth, J. (1944). Biochem. F. 38, 220.

\section{A Balance Sheet of the Estimation of Energy Intake and Energy Expenditure as Measured by Indirect Calorimetry, Using the Kofranyi-Michaelis Calorimeter}

\section{By R. PASSMORE, J. G. THOMSON AND GRACE M. WARNOCK}

WITH THF, ASSISTANCE OF

\author{
CAROL M. DIXON, A. H. KITCHIN, G. SMITH, MARGARET C. VAUGHAN \\ AND J. A. WATT \\ Department of Public Health and Social Medicine, University of Edinburgh, \\ and the Scientific Adviser's Division, Ministry of Food, London
}

(Received 30 July I 95I)

In a recent review, an expert committee of the Food and Agricultural Organization of the United Nations (1950) sets out existing physiological knowledge of energy requirements from food in relation to practical rationing problems. Throughout their report the committee again and again draw attention to the gaps in present knowledge and to the need for further investigations. One method of assessing food requirements is the measurement of energy expended (in terms of heat loss) during various physical activities. Direct measurements of the heat loss of man under varying conditions have been made. Such methods of direct calorimetry possess the advantage of great accuracy, but human calorimeters are expensive and require great skill in use. Though they are invaluable as instruments for determining basic physiological principles, they can be of little help in tackling problems of energy requirements under conditions of everyday life. Indirect calorimetry (the assessment of energy expenditure 